\title{
Presence and possible role of vascular endothelial growth factor in thyroid cell growth and function
}

\author{
J F Wang ${ }^{2}$, V Milosveski ${ }^{3}$, C Schramek ${ }^{4}$, G H Fong ${ }^{4,5}$, G P Becks ${ }^{2}$ \\ and D J Hill ${ }^{1,2,3,5}$
}

${ }^{1}$ MRC Group on Fetal and Neonatal Health and Development, Lawson Research Institute, St Joseph's Health Centre, London, Ontario, Canada N6A 4V2 and Departments of ${ }^{2}$ Medicine, ${ }^{3}$ Paediatrics, ${ }^{4}$ Biochemistry and ${ }^{5}$ Physiology, University of Western Ontario, London, Ontario, Canada N6A 5C1

(Requests for offprints should be addressed to D J Hill, Lawson Research Institute, St Joseph's Health Centre, 268 Grosvenor Street, London, Ontario, Canada N6A 4V2)

\begin{abstract}
Angiogenesis is an important component in the development of thyroid goitre. Vascular endothelial growth factor (VEGF) represents a family of specific endothelial cell mitogens involved in normal angiogenesis and in tumour development. The purpose of this study was to determine the distribution of VEGF in thyroid tissues during goitre formation, and to study the actions of VEGF on the regulation of thymidine incorporation and iodine uptake by thyroid follicular cells. Goitre was induced in adult rats by administration of methimazole together with a low iodine diet. Thyroid from normal or goitrous rats was removed, fixed and sectioned. Immunocytochemistry performed for VEGF using the avidin-biotin system showed that VEGF is present in normal thyroid and is located mainly in the vascular endothelium and interfollicular stromal tissue. After administration of goitrogen for 2 weeks, which caused a two- to threefold increase in thyroid weight, staining of VEGF was less apparent within the interfollicular stroma, but strongly increased throughout the thyroid follicular and endothelial cells. Uptake of $\left[{ }^{125} \mathrm{I}\right]$ and incorporation of $\left[{ }^{3} \mathrm{H}\right]$ thymidine by Fisher rat thyroid cells (FRTL-5) were measured after $72 \mathrm{~h}$ culture
\end{abstract}

with or without TSH or VEGF, or both. In the absence of TSH, incubation with VEGF caused a significant reduction in $\left[{ }^{3} \mathrm{H}\right]$ thymidine incorporation, but did not significantly alter $\left[{ }^{125} \mathrm{I}\right]$ uptake. Incubation with TSH $(1 \mathrm{mU} / \mathrm{ml})$ caused a fourfold increase in $\left[{ }^{3} \mathrm{H}\right]$ thymidine incorporation that was diminished by co-incubation with $10 \mathrm{ng} / \mathrm{ml}$ or greater VEGF. Similarly, $10 \mathrm{ng} / \mathrm{ml}$ or greater VEGF significantly reduced the ability of TSH to increase $\left[{ }^{125} \mathrm{I}\right]$ uptake. The antagonistic effects of VEGF on TSHstimulated $\left[{ }^{3} \mathrm{H}\right]$ thymidine incorporation or $\left[{ }^{125} \mathrm{I}\right]$ uptake were significantly reduced in the presence of an antiVEGF antiserum. A DNA fragment representing mRNA encoding the VEGF receptor, flt-1, was identified in FRTL-5 cells by reverse transcription PCR analysis, and the abundance of this fragment was increased in FRTL-5 cells cultured in the medium containing TSH $(1 \mathrm{mU} / \mathrm{ml})$ or fibroblast growth factor (FGF)-2 $(25 \mathrm{ng} / \mathrm{ml})$. These results indicated that VEGF and one of its receptors, Flt-1, are present in epithelial cells of the thyroid, and that VEGF could contribute to the regulation of development and function of thyroid epithelial cells.

Journal of Endocrinology (1998) 157, 5-12

\section{Introduction}

Thyroid gland is well vascularized, with one of the highest blood flow rates per unit weight of tissue in the body. In pathological conditions such as Graves' disease, thyroid enlargement and hyperfunction are accompanied by a markedly increased blood flow. Experimental models of goitre have shown that endothelial cells proliferate before follicular cells, perhaps because vascularization may be an important prerequisite for sustaining thyroid growth (Denef et al. 1989). During thyroid involution induced by iodide, there is a rapid contraction of capillary vascularization, again emphasizing the rapidity of response of the thyroid vasculature (Mahmoud et al. 1986, Wollman et al. 1990). Mechanisms mediating thyroid microvascular modification are not well understood. A number of growth and vasoactive factors are produced in thyroid and are considered to be potentially responsible for changes in thyroid microvasculature and blood flow (Dumont et al. 1992). We previously found that fibroblast growth factor (FGF)-2, a potent angiogenic protein, is synthesized and secreted by thyroid cells and, in cooperation with thyroidstimulating hormone (TSH), regulates the growth and function of thyroid cells (Logan et al. 1992, Becks et al. 1994, Hill et al. 1994).

Vascular endothelial growth factor (VEGF) is a homodimeric glycoprotein of $46 \mathrm{kDa}$ which is a potent mitogen for endothelial cells both in vitro and in vivo, and also has vascular permeability-enhancing activity (Ferrara et al. 1992). VEGF is expressed in many tumours, 
including human thyroid tumour cells (Inagaki et al. 1995), but is also expressed in normal keratinocytes, activated macrophages, renal mesangial cells and smooth muscle cells, suggesting a role in developmental and homeostatic, in addition to neoplastic, angiogenesis (Ferrara et al. 1992). This view is supported by the presence of VEGF mRNA and VEGF bioactivity in rat and human granulosa and theca cells, suggesting a contribution to the angiogenesis associated with the ovarian cycle (Koos 1986, Yan et al. 1993, Kamat et al. 1995). However, high levels of expression of VEGF are also detected around microvessels in areas where endothelial cells are normally quiescent (Ferrara et al. 1992). VEGF mRNA was identified in human thyroid follicles isolated from patients with Graves' disease, and shown to be increased after exposure to TSH, Graves' IgG, or insulin (Sato et al. 1995). VEGF mRNA was also detected within the thyroid gland of the rat 3 days after treatment with thiouracil to induce goitre. It therefore seems likely that VEGF is upregulated during goitre, possibly under the transcriptional control of TSH.

Two tyrosine kinase-type receptors, Flt-1 and Flk-1, have been shown to bind VEGF with high affinity (Fong et al. 1995, Sato et al. 1995). The organ distribution of flt-1 mRNA correlates well with the distribution of VEGF binding in adult tissues (Shibuya et al. 1990). Both flt-1 and flk-1 mRNAs were detected in rat thyroid after thiouracil induction of goitre (Sato et al. 1995). However, it is not clear whether VEGF and its receptors are expressed within endothelial cells or thyrocytes during the goitrous state, or whether both thyrocytes and endothelial cells are biologically responsive. The purpose of this study was therefore to examine the cellular distribution of VEGF during the formation of thyroid goitre in the rat, and to examine the possible biological actions of VEGF on rat thyrocytes.

\section{Materials and Methods}

\section{Materials}

Fisher rat thyroid (FRTL-5) cells (F2 sub-clone) were kindly provided by Dr Leonard D Kohn (Laboratory of Biochemistry and Metabolism, National Institute of Diabetes, Digestive and Kidney Disease, National Institutes of Health. Bethesda, MD, USA). Materials were purchased from the following sources: transferrin, bovine insulin, bovine TSH, hydrocortisone, glycyl-histidyllysine, somatostatin, Coon's modified F-12 M medium powder, non-essential amino acids, and ExtrAvidin peroxidase staining Kit from Sigma Chemical Co., St Louis, MO, USA $;{ }^{125}$ I-labelled sodium iodide (IMS30) from Amersham International, Mississauga, Ontario, Canada; calf serum, trypsin, collagenase, Superscript II, RNase $\mathrm{H}$ reverse transcriptase, 123 bp DNA ladder, and Taq DNA polymerase from Gibco BRL, Burlington,
Ontario, Canada. Recombinant human VEGF and antihuman VEGF neutralizing antibody were purchased from R\&D System Inc., Minneapolis, MN, USA. RNeasy Midi Kits were purchased from QIAGEN Inc., Chatsworth, CA, USA. Hexanucleotide (dN6), Ultrapure dNTP set and $2^{\prime}$-deoxynucleoside $5^{\prime}$-triphosphate were each purchased from Pharmacia Biotech Inc., Baie D’Urfe, QC, Canada.

\section{Animals}

All procedures had prior approval of the animal care committee of the University of Western Ontario and were performed in accordance with the guidelines of the Canadian Council for Animal Care. Young adult male Wistar rats weighting 250-275 g were obtained from Charles River Limited, StConstant, QC, Canada and housed with a $12 \mathrm{~h}$ light : darkness cycle. Forty rats were separated into two equal groups: one group received a low iodine formulation of rat chow $(0.05$ p.p.m.) that was isocaloric with normal diet, together with $0.01(\mathrm{w} / \mathrm{v})$ methimazole in their drinking water; the remaining animals formed a control group that received normal rat chow and tap water. Food and water were available ad libitum to both groups. Ten rats from each group were killed by $\mathrm{CO}_{2}$ asphyxiation after 1 week and the remainder were killed after 2 weeks. After rats were weighed, blood was collected by cardiac puncture and serum was prepared and frozen at $-20{ }^{\circ} \mathrm{C}$ until radioimmunoassay for thyroxine $\left(\mathrm{T}_{4}\right)$ and tri-iodothyronine $\left(\mathrm{T}_{3}\right)$. Thyroid glands were isolated, weighed, and fixed for later immunocytochemistry by immersion in $4 \%(\mathrm{w} / \mathrm{v})$ paraformaldehyde $-0 \cdot 2 \%$ glutaraldehyde in $100 \mathrm{mM}$ PBS for $24 \mathrm{~h}$, followed by two washes in PBS, each for $24 \mathrm{~h}$. Tissues were then placed in 30\% (w/v) sucrose in PBS for 5 days before dehydration in $70 \%(\mathrm{v} / \mathrm{v})$ ethanol and embedding in paraffin. All treatments were at $40{ }^{\circ} \mathrm{C}$.

\section{Uptake of $\left[{ }^{125} I\right]$ and incorporation of $\left.{ }^{3} \mathrm{H}\right]$ thymidine}

FRTL-5 cells were cultured and passaged as described by Ambesi-Impiombato \& Perrild (1989). Cells from passages 8-15 were used in these studies. Cells were cultured in $6 \mathrm{H}$ medium (F-12 medium containing TSH $(0 \cdot 1 \mathrm{IU} / \mathrm{ml})$, hydrocortisone $(0 \cdot 4 \mathrm{ng} / \mathrm{ml})$, transferrin $(5 \mu \mathrm{g} / \mathrm{ml})$, somatostatin $(10 \mathrm{ng} / \mathrm{ml})$, insulin $(10 \mu \mathrm{g} / \mathrm{ml})$, and glycyl-histidyllysine $(10 \mathrm{ng} / \mathrm{ml}))$ with $5 \%$ calf serum. The medium was changed every 3 days. Subconfluent cells were continually cultured in $5 \mathrm{H}$ medium ( $6 \mathrm{H}$ without TSH) containing $5 \%$ calf serum for $24 \mathrm{~h}$, in $4 \mathrm{H}$ medium ( $5 \mathrm{H}$ without insulin) containing $5 \%$ calf serum for $24 \mathrm{~h}$, and in $3 \mathrm{H}$ medium (transferrin, somatostatin and glycyl-histidyl-lysine) containing $2 \cdot 5 \%$ calf serum for $24 \mathrm{~h}$. Then cells were incubated in $3 \mathrm{H}$ medium without calf serum for $72 \mathrm{~h}$. TSH $(1 \mathrm{mU} / \mathrm{ml})$, VEGF or antibody against VEGF, were added alone or in combination, depending on the 
requirement of individual experiments. To estimate DNA synthesis, $\left[{ }^{3} \mathrm{H}\right]$ thymidine $(1 \mu \mathrm{Ci} /$ well $)$ was added to cells for the final $24 \mathrm{~h}$ of culture. Cell layers were washed and solubilized by $0 \cdot 1 \mathrm{M}$ sodium hydroxide. The total DNA content of cells within individual wells was measured by fluorimetry, using Hoechst fluorochrome 33258, as described previously (Hill \& DeSousa 1990). In separate experiments, cells were washed with PBS and then incubated with F-12 medium containing 100000 c.p.m. carrier-free ${ }^{125}$-labelled sodium iodide for $30 \mathrm{~min}$. [ $\left.{ }^{3} \mathrm{H}\right]$ incorporation and $\left[{ }^{125} \mathrm{I}\right]$ uptake by cells were calculated as c.p.m./ $\mu$ g DNA.

\section{Immunocytochemistry}

Tissue sections $(5 \mu \mathrm{m})$ in paraffin were prepared for immunocytochemistry and after rehydration in a descending ethanol series, and sections were incubated in $1 \%(\mathrm{v} / \mathrm{v})$ hydrogen peroxide to block endogenous peroxide activity, followed by a $15 \mathrm{~min}$ incubation in 5\% BSA in PBS to reduce non-specific binding. Slides were incubated for $48 \mathrm{~h}$ at $40{ }^{\circ} \mathrm{C}$ in a humidified chamber with a primary antibody against VEGF at a dilution of $1: 1000$ in PBS $(\mathrm{pH} 7 \cdot 5)$ containing $2 \%(\mathrm{w} / \mathrm{v})$ BSA and $0 \cdot 01 \%$ sodium azide (100 $\mu \mathrm{l}$ per slide). All subsequent incubations were at room temperature. An appropriate biotinylated anti- $\operatorname{IgG}$ antibody diluted $1: 500$ in the same buffer was applied for $2 \mathrm{~h}$, then slides were washed in PBS and incubated with avidin and biotinylated horseradish peroxidase for $1 \mathrm{~h}$. After washing in PBS followed by $50 \mathrm{mM}$ Tris- $\mathrm{HCl}(\mathrm{pH}$ $7 \cdot 5$ ), the peptide immunoreactivity was localized by incubation in fresh $1.89 \mathrm{mM}$ diaminobenzidine with $0.03 \%$ $(\mathrm{v} / \mathrm{v})$ hydrogen peroxide for $2 \mathrm{~min}$ and the reaction was quenched in excess $50 \mathrm{mM}$ Tris- $\mathrm{HCl}(\mathrm{pH}$ 7.5). Tissue sections were counterstained with Carazzi's haematoxylin, dehydrated in an ascending ethanol series, cleared with xylene and mounted under glass coverslips. Negative controls included preabsorbtion of the primary antibody with VEGF and incubation of sections without primary or second antibody.

\section{Reverse transcription-PCR analysis}

To examine whether VEGF receptors were present in thyroid cells, FRTL-5 cells were cultured in $6 \mathrm{H}$ medium containing 5\% calf serum to subconfluency. Subconfluent cells were furthered cultured for 3 days in serum-free $3 \mathrm{H}$ medium containing TSH $(1 \mathrm{mU} / \mathrm{ml})$ or FGF-2 (25 ng/ $\mathrm{ml}$ ) or in $6 \mathrm{H}$ medium containing $5 \%$ calf serum. After washing with ice-cold PBS buffer, total RNA was isolated from cells by acid guanidinum thiocyanate-phenolchloroform extraction (Chomczynski \& Sacchi 1987). Total RNA was isolated from adult rat or mouse gut and intestine by RNease Midi Kits following the instruction provided by the manufaturer. RT-PCR analysis was performed as previously described (Fong et al. 1995). In
Table 1 Increase in thyroid wet weight and decrease in plasma concentrations of tri-iodothyronine $\left(T_{3}\right)$ and thyroxine $\left(T_{4}\right)$ in rats maintained on a low iodine diet and receiving methimazole for 2 weeks, compared with control animals. Values are means \pm S.D. Each group comprised 10 animals

\begin{tabular}{|c|c|c|c|}
\hline & $\begin{array}{l}\text { Thyroid weight } \\
\text { (mg/100 g } \\
\text { body weight) }\end{array}$ & $\begin{array}{l}\mathbf{T}_{3} \\
(\mathrm{nM})\end{array}$ & $\begin{array}{l}\mathbf{T}_{\mathbf{4}} \\
(\mathrm{nM})\end{array}$ \\
\hline Low iodine diet & $27 \pm 4^{*}$ & $0 \cdot 5 \pm 0 \cdot 1^{*}$ & $\mathrm{ND}$ \\
\hline Control diet & $5 \pm 1$ & $1 \cdot 6 \pm 0 \cdot 1$ & $66 \pm 4$ \\
\hline
\end{tabular}

brief, the total RNA $(10 \mu \mathrm{g})$ isolated either from FRTL-5 cells or from rat or mouse tissues was used as the template in each reverse transcription reaction, using dN6 random hexamer as primers. The conditions for reverse transcription were based on the protocol provided by Gibco-BRL. The amount of available template was further standardized by PCR amplification of the $\beta$-actin signal from each sample (not shown). The following oligonucleotides were used for the amplification of rat flk-1 and flt-1 using Taq DNA polymerase: sense rft-1 (5'CATGGTCAGCTGC TGGGACACCGCG3', antisense rftt-1 (5'GACTCCCT GCATCACTAACAATAT3'); sense rflk-1 (5'TCAGAT TACTTGCAGGGGACAGAGG3') and antisense flk-1 (5'GGATCACCACAGTTTTGTTCTTGTT3'). Separate primers were used for the amplification of flt-1 depicted in Fig. 6: sense (5'CGCGGTCTTGCCTTAC GCGCT3') and antisense (5'CCATTTATGGGCTGCT TCCCCCCTGCA3'). Pilot experiments were performed for the amplification of flk-1 and flt-1 sequences from the RNA extracted from rat tissues and the FRTL- 5 cell line. These amplifications demonstrated linearity up to 35 cycles under our conditions. For the amplification of both flk-1 and flt-1, the following cycle parameters were used: $94{ }^{\circ} \mathrm{C}$ for $45 \mathrm{~s}, 62^{\circ} \mathrm{C}$ for $30 \mathrm{~s}$, and $72{ }^{\circ} \mathrm{C}$ for $2 \mathrm{~min}$. The reactions were allowed to repeat for 35 cycles for flt- 1 and 36 cycles for flk-1.

\section{Statistical analysis}

The differences in $\left[{ }^{3} \mathrm{H}\right]$ thymidine incorporation and uptake of $\left[{ }^{125} \mathrm{I}\right]$ by FRTL-5 cells between control and experimental groups were analysed by Student's $t$-test. Each experiment was repeated at least three times. Representative photomicrographs of VEGF immunohistochemical distribution in rat thyroid are shown.

\section{Results}

After 2 weeks on a low iodine diet and receiving methimazole, rats demonstrated more than a doubling in thyroid weight, relative to body weight, compared with 

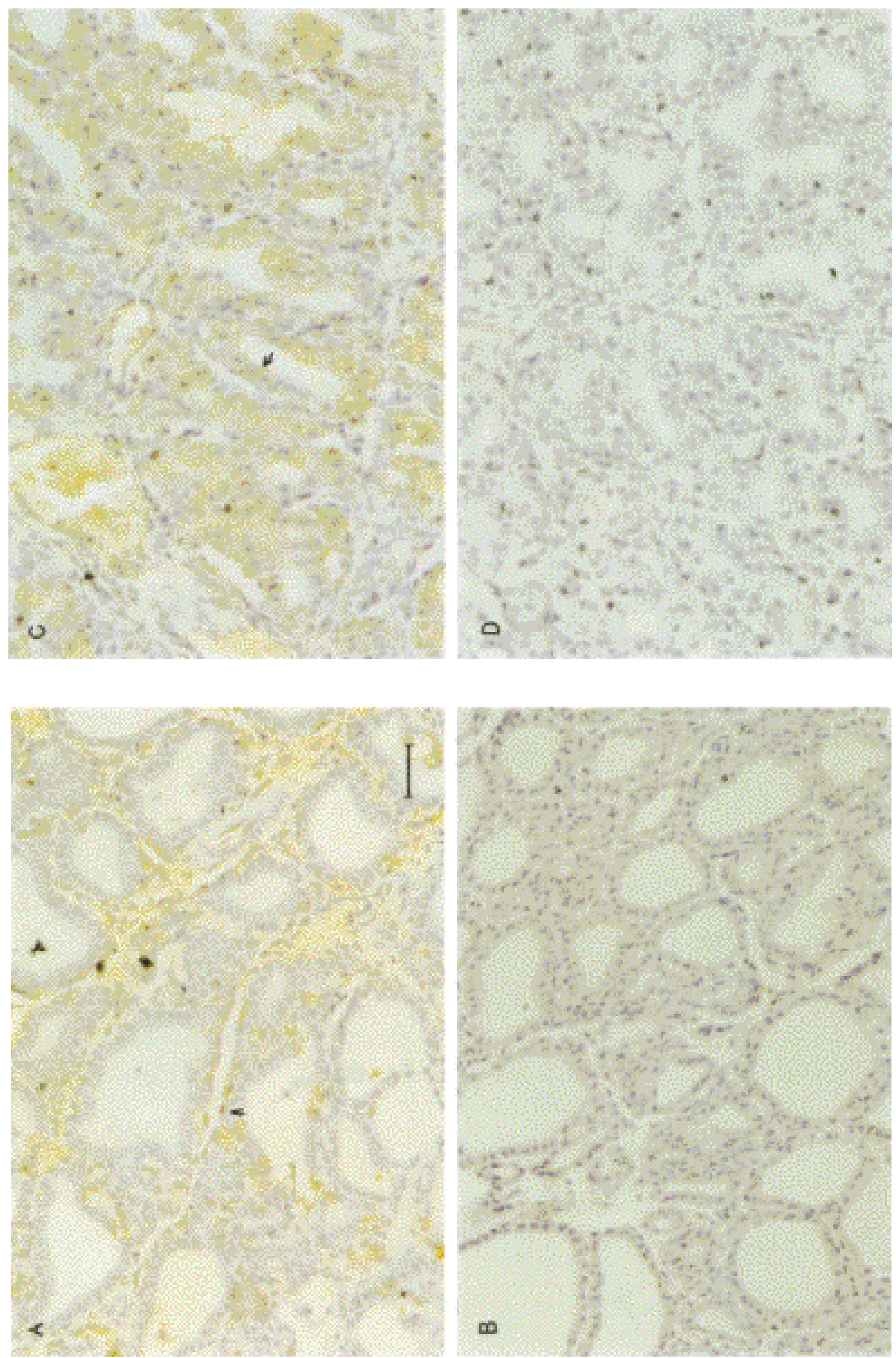
control animals. In comparison with controls, rats on the goitrous regime also demonstrated a significant reduction in serum concentrations of $\mathrm{T}_{4}$ and $\mathrm{T}_{3}$ (Table 1).

VEGF immunoreactivity was found in sections of both normal and goitrous rat thyroid tissues by immunohistochemistry (Fig. 1A and C). In contrast, positive staining of VEGF was not found when the primary antibody was omitted or was preabsorbed with excess antigen. In sections of normal rat thyroid, the follicles are large and filled with abundant colloid. VEGF staining was mainly localized to the vascular endothelium and intrafollicular stromal tissue, but was less abundant in thyroid epithelial cells. In sections of hyperplastic rat thyroid tissues, less colloid was present and the thyrocytes were hypertrophic and cuboid. The area of VEGF staining was obviously increased throughout the thyroid tissue in both endothelial and epithelial cells in the goitrous gland. A similar immunohistochemical distribution of VEGF was seen both 1 and 2 weeks after administration of goitrogen.

VEGF caused a dose-dependent inhibition of both TSH-stimulated DNA synthesis and uptake of $\left[{ }^{125} \mathrm{I}\right]$ that was significant at concentrations of $10 \mathrm{ng} / \mathrm{ml}$ or greater (Figs $2 b$ and $3 b$ ). VEGF alone caused an inhibition of basal incorporation of $\left[{ }^{3} \mathrm{H}\right]$ thymidine at concentrations of $10 \mathrm{pg} / \mathrm{ml}$ or greater, but did not significantly affect basal uptake of $\left[{ }^{125} \mathrm{I}\right]$ (Figs $2 a$ and $3 a$ ). These results indicate that VEGF could modulate the stimulatory effect of TSH on the incorporation of $\left[{ }^{3} \mathrm{H}\right]$ thymidine and uptake of iodine in cultured FRTL-5 cells. The effects of VEGF on TSH-stimulated DNA synthesis were inhibited in the presence of increasing concentrations of an antibody against VEGF, indicating that the effects of VEGF were specific (Fig. 4). Similarly, antibody against VEGF reversed the inhibitory action of VEGF on TSHdependent iodine uptake, but did not alter basal DNA synthesis in the absence of TSH or VEGF (not shown). The presence of mRNAs encoding the VEGF receptors, flt-1 and flk-1, in FRTL-5 cells was examined using RT-PCR. Total RNA extracted from rat lung and intestine, and DNA fragments encoding the VEGF receptors, flt-1 and flk-1, were used as positive controls (Fig. 5). An flt-1 DNA amplification fragment of the predicted size of $400 \mathrm{bp}$ was found to be expressed in FRTL-5 cells after their incubation in $6 \mathrm{H}$ medium, but no flk-1 amplification product of predicted size $300 \mathrm{bp}$ was found, despite this being present in rat lung and intestine. As the PCR was performed within the linear range of amplification for all the samples, the results indicate that the level of expression of flt-1 mRNA in FRTL- 5 cells is of magnitude similar to that in the two vascular endothelial cell-rich tissues used as controls. The amplification signal for flt-1 in FRTL-5 cells was greater in cells cultured in serum-free $3 \mathrm{H}$ medium containing TSH $(1 \mathrm{mU} / \mathrm{ml})$ and FGF-2 (25 ng/ml) than in 6H medium (Fig. 6).

\section{Discussion}

The coordination of thyroid epithelial cell growth with that of mesenchymal tissues such as endothelial and stromal cells is required for the homeostasis of thyroid gland in either physiological or pathological conditions. Whereas TSH is a major stimulus to thyrocyte iodide metabolism, growth of the thyroid involves interactions between TSH and locally derived autocrine or paracrine factors (Dumont \& Vassart 1995). Multiple growth factors including FGF-2, transforming growth factor $\beta$ (TGF $\beta$ ), epidermal growth factor (EGF) and the insulin-like growth factors (IGFs) and their associated binding proteins (IGFBPs) have been found in thyroid tissues. These growth factors have been implicated in the regulation of thyroid growth during goitre formation, and also modulate the metabolic effects of TSH on thyroid cells (Westermark et al. 1983, Bachrach et al. 1985, Morris et al. 1988, Wang et al. 1990, Cowin et al. 1992, Logan et al. 1992, Becks et al. 1994, Hill et al. 1994). Proliferation of endothelial cells, expansion of vascular spaces and increase in local blood flow are all hallmarks of iodine-deficient goitre (Denef et al. 1989). VEGF mRNA and that of its receptors were found to be present in the human and rat thyroid, and to be upregulated in the rat shortly after the induction of goitre (Sato et al. 1995). In this study, we have found that the distribution of VEGF is limited largely to the vascular endothelium in the normal rat thyroid, but is substantially altered in goitrous tissue, to include most thyrocytes. This supports a role for locally derived VEGF in the angiogenesis of goitre, but raises the question of whether endothelial cells alone are the target population, or if thyrocytes are also responsive.

The presence of both flt-1 and flk- 1 mRNA has been reported in rat thyroid after the induction of goitre, although no mRNA was found in human thyroid from patients with Graves' thyroiditis (Sato et al. 1995). The cellular location of these receptors was not identified, but a most obvious possibility would be their upregulation in thyroid endothelial cells. With a combination of immunohistochemistry for VEGF and RT-PCR to identify flt-1 and flk-1, we have obtained evidence that at least one of these receptors, Flt-1, is also expressed in thyroid epithelial cells. This surprising result suggests possible biological actions of VEGF on the thyrocyte population. Consistent with this idea, we found that VEGF, previously

Figure 1 Immunocytochemistry staining for VEGF in normal (A) and hyperplastic (C) rat thyroid sections, and controls (B and D). Arrows denote staining of the vascular endothelial cells in $\mathrm{A}$, and of the hyperplastic thyrocytes in $\mathrm{C}$. In the control sections the primary antibody against VEGF was omitted in the incubation. Horizonal bar represents $75 \mu \mathrm{m}$. 


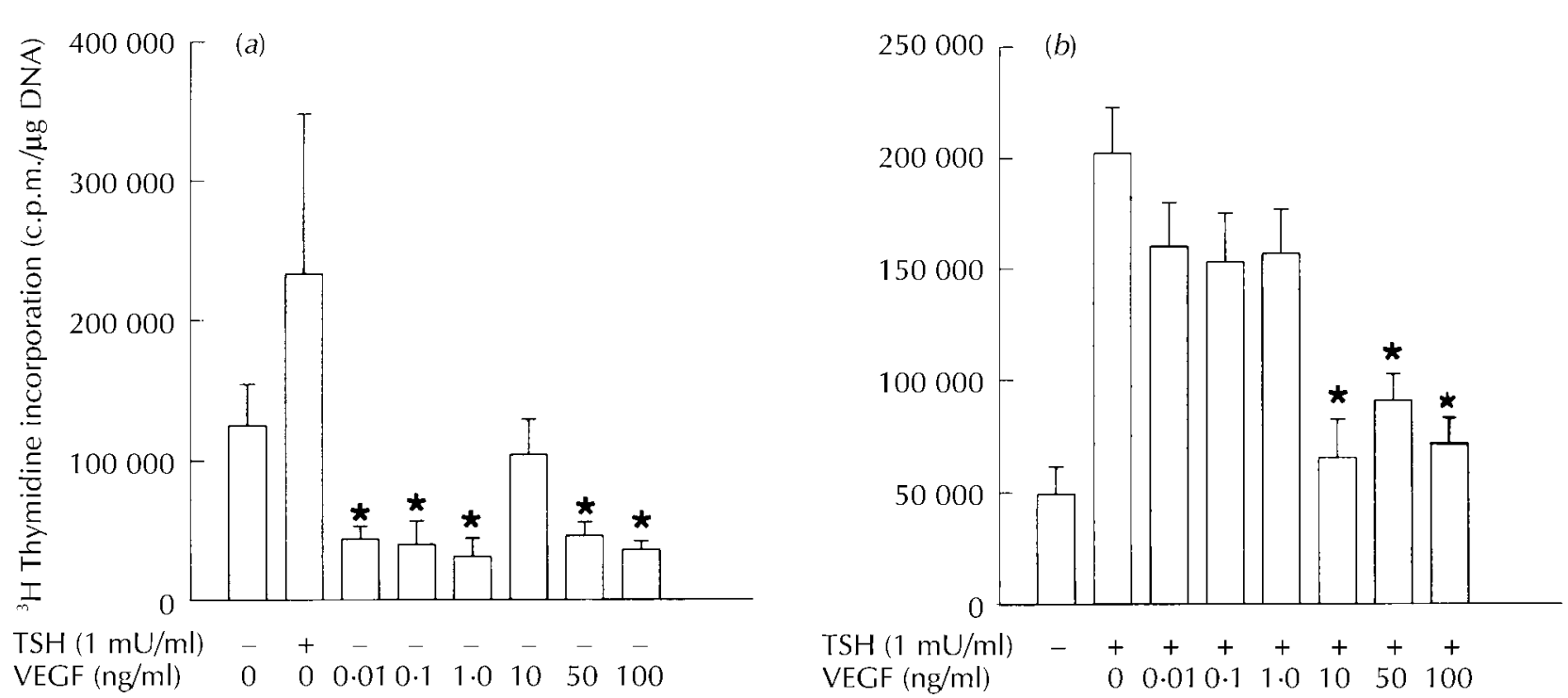

Figure 2 Effect of VEGF on $\left.{ }^{3} \mathrm{H}\right]$ thymidine incorporation (expressed as c.p.m./ $\mu$ g DNA) by rat thyroid (FRTL-5) cells. Subconfluent FRTL-5 cells were cultured in serum-free $3 \mathrm{H}$ medium for $72 \mathrm{~h}$. VEGF alone (a) or in combination with TSH ( $1 \mathrm{mU} / \mathrm{ml})(b)$ was added to cultures in increasing concentrations. $\left[{ }^{3} \mathrm{H}\right]$ Thymidine $\left(1 \mu \mathrm{Ci} /\right.$ well) was added at the last $24 \mathrm{~h}$ incubation. ${ }^{*} P<0 \cdot 05$ or better compared with control (a) or TSH alone $(b) ; n=3$.
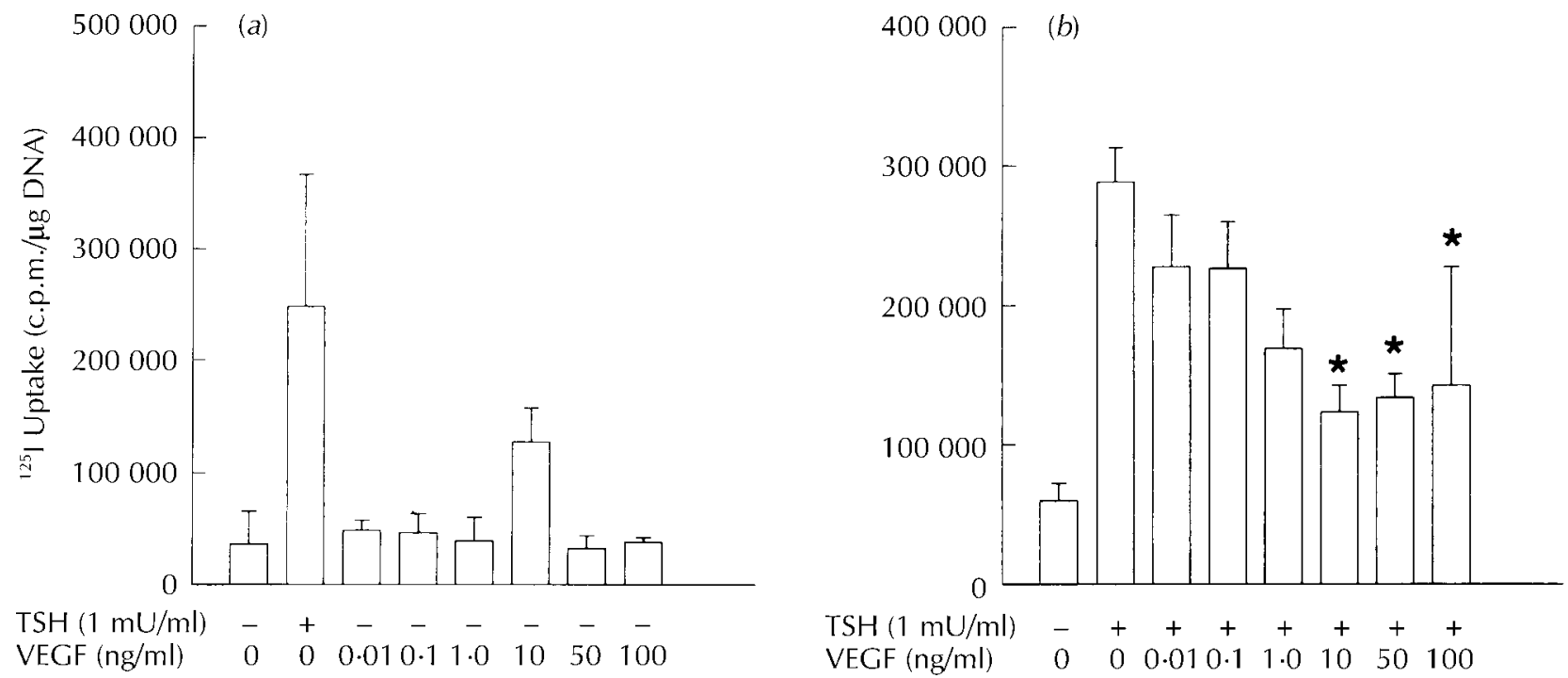

Figure 3 Effect of VEGF on uptake of $\left[{ }^{125} \mathrm{I}\right]$ (expressed as c.p.m./ $\mu$ g DNA) by rat thyroid (FRTL-5 ) cells. Subconfluent FRTL-5 cells were cultured in serum-free $3 \mathrm{H}$ medium for $72 \mathrm{~h}$. VEGF alone (a) or in combination with TSH $(1 \mathrm{mU} / \mathrm{ml})(b)$ was added to cultures in increasing concentrations. ${ }^{*} P<0.05$ or better compared with control (a) or TSH alone $(b) ; n=3$.

recognized as an endothelium-specific mitogen, inhibited both TSH-dependent DNA synthesis and iodide uptake by FRTL-5 cells. The mitogenic actions of VEGF on endothelial cells are mediated primarily by interactions with Flk-1 (Waltenberger et al. 1994). The probable mediation of the growth-inhibitory effects of VEGF on thyrocytes in this study via the Flt-1 receptor suggests that the two VEGF receptors can induce opposite biological responses to the same ligand. The localization of VEGF immunoreactivity to endothelial cells in the normal rat thyroid may represent the association of ligand expressed by surrounding stromal cells with Flt-1 receptors, as little VEGF has been found to be expressed by endothelial cells in other tissues.

Sustained increases in serum TSH after administration of a goitrogen causes three phases of thyroid growth in rat: an initial 1-2 month period of rapid proliferation of follicular and stromal cells is followed by a long plateau phase during which little or no growth occurs, and finally, after 6-12 months, follicular cell tumours begin to appear 


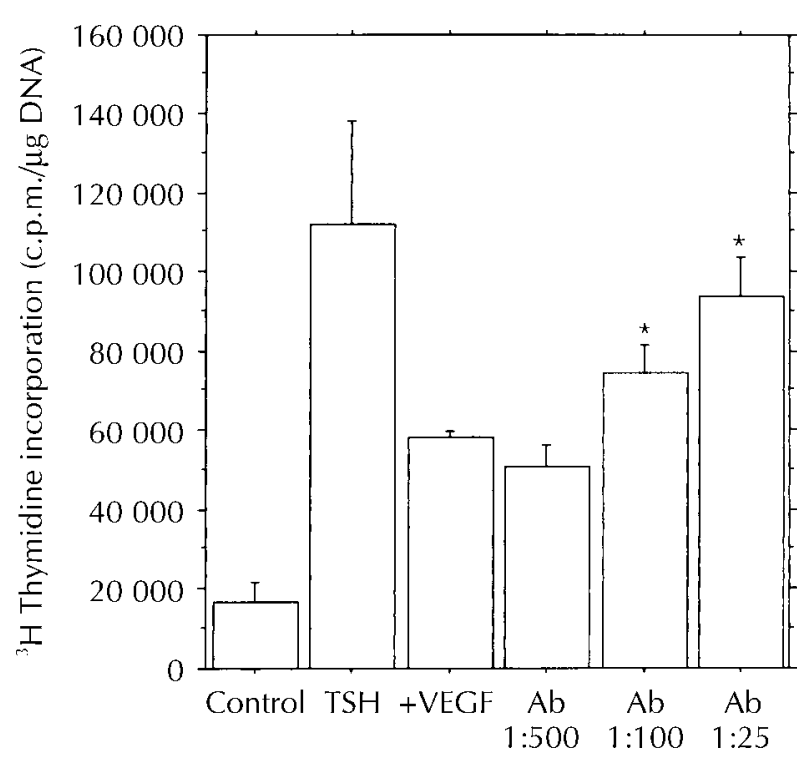

Figure 4 Effect of antibody against VEGF on incorporation of $\left[{ }^{3} \mathrm{H}\right]$ thymidine (expressed as c.p.m./ $\mu$ g DNA) by FRTL-5 cells. Subconfluent FRTL-5 cells were cultured in serum-free $3 \mathrm{H}$ medium for $72 \mathrm{~h}$. TSH $(1 \mathrm{mU} / \mathrm{ml})$ and VEGF $(10 \mathrm{ng} / \mathrm{ml})$, alone or in combination, were added to cultures without or with the further addition of antibody (Ab) against VEGF at $1: 25,1: 100$ or $1: 500$ dilution. ${ }^{*} P<0 \cdot 05$ or better compared with TSH+VEGF without antibody; $n=3$.

(a)

$$
\text { MW W I L } 6
$$

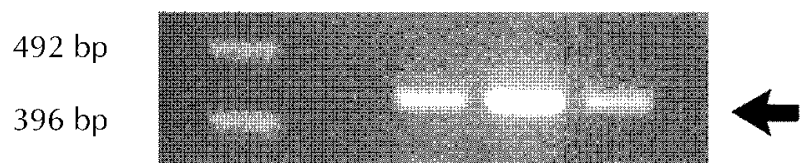

(b)

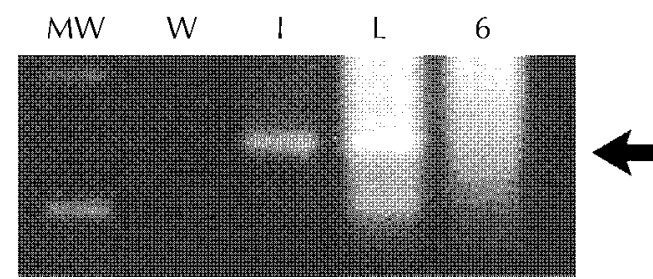

Figure 5 RT-PCR analysis of total RNA from FRTL-5 cells. Subconfluent FRTL-5 cells were cultured in $6 \mathrm{H}$ medium containing $5 \%$ calf serum (6) for $72 \mathrm{~h}$. Total RNA was isolated and analysed by RT-PCR using oligonucleotides specific for flt-1 (a), or flk-1 (b). Total RNAs extracted from adult rat lung (L) or intestine (I) were used as positive controls. Water alone without added RNA was used as a negative control (W).

(Wynford-Thomas et al. 1983). An increased presence of VEGF mRNA occurs in the rat thyroid within 3 days of the induction of goitre and has been directly linked to the presence of increased concentrations of TSH (Sato et al. 1995). This would coincide with a rapid proliferation of endothelial cells required to support goitre formation, but also with a hyperplasia of thyrocytes. It is possible that VEGF provides a short-loop feedback system to limit
246 bp

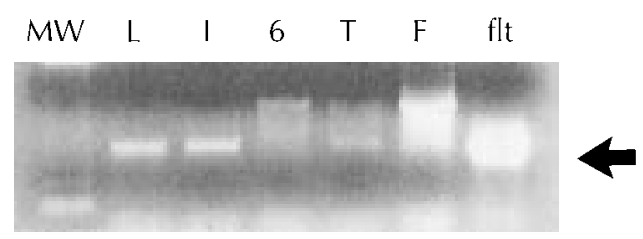

Figure 6 RT-PCR analysis of total RNA from FRTL-5 cells. Subconfluent FRTL-5 cells were cultured in $6 \mathrm{H}$ medium containing $5 \%$ calf serum (6), serum-free $3 \mathrm{H}$ medium containing TSH $(1 \mathrm{mU} / \mathrm{ml})(\mathrm{T})$ or FGF-2 $(25 \mathrm{ng} / \mathrm{ml})$ (F) for $72 \mathrm{~h}$. Total RNA was isolated and analysed by RT-PCR using an oligonucleotide specific for flt-1. Total RNAs extracted from adult mouse lung (L) or intestine (I) were used as positive controls, together with the flt- 1 oligonucleotide sequence (flt).

thyrocyte proliferation, and to maintain a balance between thyrocyte mass and the expanding capillary network. It may contribute to the subsequent plateau of thyroid growth seen after goitre is induced in vivo. In this role VEGF, would oppose the actions of locally produced FGF-2 and IGF-I, which are also increased in abundance during goitre in rats, but which partly mediate the mitogenic actions of TSH (Becks et al. 1994, Hill et al. 1994, Phillips et al. 1994). An inhibitory influence of VEGF on thyrocyte proliferation would be additive to the effects of locally produced TGF $\beta$ (Logan et al. 1994). Interactions may exist between the expression of VEGF and the presence of other growth factors during goitre, as VEGF expression was induced in fibroblast and epithelial cells in response to TGF $\beta$ (Pertovaara et al. 1994). The relationship between FGF-2 and VEGF is unknown, but demonstration of the presence of flt-1 mRNA in FRTL-5 cells by RT-PCR in this study suggests that the amplification signal for flt- 1 is greater after the exposure of cells to either FGF-2 or TSH.

The intracellular second-messenger signals that mediate the mitogenic actions of VEGF on endothelial cells are unique. While autophosphorylation of Flt-1 on endothelial cells induced the phosphorylation of phospholipase-C gamma and GTPase-activating protein complex on both endothelial cells and transfected NIH-3T3 cells, only in the former did this result in cell proliferation (Seetharam et al. 1995). The second-messenger signals that might mediate the ability of VEGF to inhibit TSH-dependent DNA synthesis or uptake of iodine by FRTL- 5 cells are unknown, as is their interaction with the increased generation of cAMP and activation of protein kinase-A, which mediates the growth and metabolic effects of TSH.

In summary, VEGF and its specific receptor, Flt-1, are found in thyroid cells, and the presence and distribution of VEGF in thyroid tissues is increased during goitre formation. VEGF reversed the stimulatory effect of TSH on iodine uptake and DNA synthesis in FRTL-5 rat thyrocytes. These observations indicate that VEGF could be involved in the local regulation of thyrocyte 
proliferation and differentiation. The interactions of TSH with VEGF through different receptors and their associated second-messenger systems during goitre formation remain to be investigated.

\section{Acknowledgements}

We are grateful to the Medical Research Council of Canada for financial assistance to Drs G P Becks, G H Fong and D J Hill.

\section{References}

Ambesi-Impiombato FS \& Perrild H (Eds) 1989 FRTL-5 Today, pp 1-348. Amsterdam: Elsevier Science Publishers.

Bachrach LK, Eggo MC, Mak WW \& Burrow GN 1985 Phorbol esters stimulate growth and inhibit differentiation in cultured thyroid cells. Endocrinology 116 1603-1609.

Becks GP, Logan A, Phillips ID, Wang JF, Smith C, DeSousa D \& Hill DJ 1994 Increase of basic fibroblast growth factor (FGF) and FGF receptor RNA during rat thyroid hyperplasia: temporal changes and cellular distribution. Journal of Endocrinology 142 325-338.

Chomczynski P \& Sacchi N 1987 Single-step method of RNA isolation by acid guanidinium thiocyanate-phenol-chloroform extraction. Annals of Biochemistry 162 156-159.

Cowin AJ, Davis JR \& Bidey SP 1992 Transforming growth factor- $\beta$ production in porcine thyroid follicular cells: regulation by intrathyroidal organic iodine. Molecular Endocrinology 5 197-205.

Denef JF, Ovaert C \& Many MC 1989 Experimental goitrogenesis. Annals of Endocrinology $\mathbf{5 0} 1-15$.

Dumont J \& Vassart G 1995 Thyroid regulation. In Endocrinology, edn 3, pp 543-559. Ed LJ Deroot. Philadelphia: WB Saunders.

Dumont JE, Herveg JP \& Tachiwaki O 1992 Physiological and pathological regulation of thyroid cell proliferation and differentiation by thyrotropin and other factors. Physiological Reviews 72 667-697.

Ferrara N, Houck K, Jakeman L \& Leung DW 1992 Molecular and biological properties of the vascular endothelial growth factor family of proteins. Endocrine Reviews 13 18-32.

Fong G-H, Rossant J, Gertsenstein M \& Breitman ML 1995 Role of Flt-1 receptor tyrosine kinase in regulating the assembly of vascular endothelium. Nature 376 66-69.

Hill DJ \& DeSousa D 1990 Insulin is a mitogen for isolated epiphyseal growth plate chondrocytes from the fetal lamb. Endocrinology 126 2661-2670.

Hill DJ, Phillips ID, Wang JF \& Becks GP 1994 Basic fibroblast growth factor (basic FGF) in isolated ovine thyroid follicles: thyrotropin stimulation and effects of basic FGF on DNA synthesis, iodine uptake and organification and the release of insulin-like growth factors (IGFs) and IGF binding proteins. Thyroid 4 77-85.

Inagaki A, Iwase K, Tsujimura T, Jimbo S \& Miura K 1995 Immunohistochemical study of vascular endothelial growth factor in thyroid disorder. Thyroid 5 (Suppl. 1) p 309 (Abstract P27).

Kamat BR, Brown LF, Manseau EJ, Senger DR \& Dvorak HF 1995 Expression of vascular permeability factor/vascular endothelial growth factor by human granulosa and theca lutin cells. Role in corpus luteum development. American Journal of Pathology 146 $157-165$.
Koos AD 1986 Stimulation of endothelial cells proliferation by rat granulosa cell-conditioned medium. Endocrinology 119 481-489.

Logan A, Black EG, Gonzalez AM, Buscalia M \& Sheppard MC 1992 Basic fibroblast growth factor: an autocrine mitogen of rat thyroid follicular cells? Endocrinology 130 2363-2372.

Logan A, Smith C, Becks GP, Gonzalez AM, Phillips ID \& Hill DJ 1994 Enhanced expression of transforming growth factor- $\beta 1$ during thyroid hyperplasia in rats. Journal of Endocrinology 141 45-57.

Mahmoud I, Colin IM, Many MC \& Denef JF 1986 Direct toxic effect of iodide in excess on iodine-deficient thyroid glands: epithelial necrosis and inflammation associated with lipofusin accumulation. Experimental Molecular Pathology 44 259-271.

Morris III JC, Ranganathan G, Hay ID, Nelson RE \& Jiang NS 1988 The effects of transforming growth factor- $\beta$ on growth and differentiation of the continuous rat thyroid follicular cell line FRTL-5. Endocrinology 123 1385-1394.

Pertovaara L, Kaipainen A \& Mustonen T 1994 Vascular endothelial growth factor is induced in response to transforming growth factor- $\beta$ in fibroblast and epithelial cells. Journal of Biological Chemistry $2696271-6274$.

Phillips ID, Becks GP, Wang J-F, Han VKM, Delhanty PJD \& Hill DJ 1994 Hormonal regulation and biological actions of insulin-like growth factor binding proteins (IGFBPs) expressed and released by isolated ovine thyroid follicles. Endocrinology 134 1238-1246.

Sato K, Yamazaki K, Kanaji Y, Ohsumi K, Demura H, Yamaguchi S \& Shibuya M 1995 Stimulation by thyroid-stimulating hormone and Grave's immunoglobulin $G$ of vascular endothelial growth factor mRNA expression in human thyroid follicles in vitro and $\mathrm{ftt}$ mRNA expression in the rat thyroid in vivo. Journal of Clinical Investigation 96 1295-1302.

Seetharam L, Gotoh N, Maru Y, Neufeld G, Yamaguchi S \& Shibuya M 1995 A unique signal transduction from FLT tyrosine kinase, a receptor for vascular endothelial growth factor VEGF. Oncogene 10 135-147.

Shibuya M, Yamaguchi S, Yamane A, Ikada T, Matsushime H \& Sato M 1990 Nucleotide sequence and expression of a novel human receptor-type tyrosine kinase (ft) closely related to the fms family. Oncogene 8 519-527.

Waltenberger J, Claesson-Welsh L, Siegbahn A, Shibuya M \& Heldin $\mathrm{C}-\mathrm{H} 1994$ Different signal transduction properties of KDR and Flt-1 two receptors for vascular endothelial growth factor. Journal of Biological Chemistry 269 26988-26995.

Wang JF, Becks GP, Buckingham KD \& Hill DJ 1990 Characterization of insulin-like growth factor binding proteins secreted by isolated sheep thyroid epithelial cells. Journal of Endocrinology 125 439-448.

Westermark K, Karlsson FA \& Westermark B 1983 Epidermal growth factor modulates thyroid growth and function in culture. Endocrinology 110 1680-1686.

Wollman SH, Herveg JP \& Tachiwaski O 1990 Histological changes in tissue components of the hyperplastic thyroid gland during its involution in the rat. American Journal of Anatomy 198 35-44.

Wynford-Thomas D, Stringer BMJ, Gomez Morales M \& Williams ED 1983 Vascular changes in early TSH-induced thyroid tumours in the rat. British Journal of Cancer 47 861-865.

Yan Z, Weich HA, Bernart W, Breckwoldt M \& Neulen J 1993 Vascular endothelial growth factor (VEGF) messenger ribonucleic acid (mRNA) expression in luteinized human granulosa cells in vitro. Journal of Clinical Endocrinology and Metabolism 77 1723-1725.

Received 24 April 1997

Accepted 9 September 1997 